\title{
TINGKAT PENGETAHUAN SISWA SD BINA PUTRA SURABAYA TENTANG MAJALAH DINDING SEKOLAH
}

\author{
Yustisia Ditya Sari ${ }^{1^{*}}$; Grace Swestin ${ }^{1}$ \\ ${ }^{1}$ Program Studi Ilmu Komunikasi, Fakultasa Ilmu Komunikasi, Universitas Kristen Petra \\ Jalan Siwalankerto 121-131, Surabaya 60236, INDONESIA \\ * Korespondensi penulis, e-mail: yustisia@petra.ac.id
}

\begin{abstract}
ABSTRAK
Penelitian ini melihat tingkat pengetahuan atau respon kognitif siswa-siswi SD Bina Putra Surabaya pada fungsi, sifat dan format informasi dalam majalah dinding (mading) sebagai media komunikasi sekolah. Ketika akses media komunikasi di sekolah cukup terbatas, sebagai media komunikasi yang praktis dan sederhana, keberadaan mading menjadi penting sebagai media penyampai informasi untuk menciptakan sekaligus memelihara komunikasi di antara publik internal. Dalam hal ini, dibutuhkan pengetahuan publik tentang informasi. Penelitian ini menggunakan teori Stimulus Organisme Respon (S-O-R). Responden dalam penelitian ini adalah siswa kelas 4, 5 dan 6. Dengan menggunakan metode survey dan analisis deskriptif, penelitian ini menemukan bahwa tingkat pengetahuan siswa termasuk dalam kategori tinggi. Artinya, mading tersebut dapat menjalankan fungsinya sebagai media komunikasi bagi siswa-siswa di sekolah. Namun, beberapa aspek yang dapat ditingkatkan lagi adalah pada sifat kebaruan konten mading, sifat faktual (isi tentang kejadian-kejadian sebenarnya) serta berita dan artikel tentang peristiwa dan kejadian di sekitar sekolah. Hal ini menunjukkan perlunya peningkatan aspek jurnalistik mading sebagai media komunikasi di SD Bina Putra.
\end{abstract}

Kata kunci: Tingkat pengetahuan; siswa SD Bina Putra; majalah dinding sekolah.

\begin{abstract}
The purpose of this research is to delve into the level of knowledge or cognitive response of students at Bina Putra Elementary School Surabaya on the function, nature, and format of their wall magazine as the school's communication media. Due to various limitations in the access to information experienced by the students, wall magazine becomes the simplest and most practical means of delivering information about the values and activities in the organization. That is why knowledge of information in the wall magazine becomes significant. This research utilizes Stimulus-Organism-Response (S$O-R$ ) theory and surveyed students in the $4^{\text {th }}$ to $6^{\text {th }}$ grade who are both audience and producers of the wall magazine content. The descriptive analysis reveals that the students have a high level of knowledge on the information posted. This implies that the wall magazine is able to serve as a communication medium for the students. However, the findings also suggest that students' knowledge is relatively lower on aspects ofnewness and factuality of information as well as news and articles on events happening around the school. The result shows that the journalistic aspect of the wall magazine needs to be improved.
\end{abstract}

Keywords: Level of knowledge; students; Bina Putra Elementary School; wall magazine.

\section{PENDAHULUAN}

Sebagai media komunikasi yang praktis dan sederhana, keberadaan Majalah Dinding (MaDing) menjadi penting untuk menciptakan sekaligus memelihara komunikasi di antara publik internal organisasi. Komunikasi melalui mading sekalipun bersifat satu arah atau one way communication namun bermanfaat untuk memelihara komunikasi dengan publik organisasi. Majalah dinding juga dapat dikategorikan sebagai produk media massa. Dalam beberapa literatur, majalah dinding dapat dikatakan sebagai salah satu penerbitan (publication) dalam "ragam pers khusus" yang lingkupnya adalah lingkungan sekolah (Santoso, 2007; Widayati, 1996).
Sekalipun mading adalah media komunikasi yang sederhana namun dalam pengelolaannya, mading dapat memuat nilai-nilai, harapan maupun aktivitas organisasi sehingga publik internal dapat berpartisipasi dalam merealisasikan tujuan organisasi. Dalam hal ini, dibutuhkan awareness atau pengetahuan publik internal terhadap informasi yang disediakan oleh organisasi melalui media organisasi.

Pengetahuan dapat didefinisikan sebagai informasi yang disimpan di dalam ingatan ketika seseorang menerima sebuah informasi. Seseorang mengetahui berarti ia mengamati secara langsung, memiliki pengalaman, mengenali atau sudah biasa terhadap sesuatu hal, menginsafi kesamaan dengan sesuatu 
yang sudah lebih dulu diketahui, memahami, meyakini, atau merasa pasti serta menyadari kebenaran tentang suatu hal (Engel, Blackwell, \& Miniard, 1994, p. 316). Lebih lanjut Engel, et.al., memaparkan bahwa seberapa banyak informasi yang diterima seseorang yang tersimpan dalam ingatan ketika menerima informasi bergantung pada bagaimana stimulus yang diberikan pada awalnya, yang membuat individu itu mulai berpikir sampai dengan menghasilkan respon (p. 337).

Dalam penelitian ini, stimulus yang dimaksud adalah pesan yang disampaikan dalam bentuk majalah dinding, organisme adalah komunikan yang diterpa oleh pesan tersebut, yakni siswa-siswi SD Bina Putera, sementara respon yang dimaksud adalah respon kognitif berupa tingkat pengetahuan. SD Bina Putra dipilih sebagai lokasi penelitian karena karakteristik dan latar belakangnya yang menarik. Bangunan SD Bina Putra terdiri dari dua bangunan yang mengapit sebuah gang kecil yang hanya dapat dilewati oleh sebuah sepeda motor. Di seberang SD Bina Putra terdapat sebuah Tempat Pemakaman Umum, sementara di belakang SD tersebut adalah pemukiman warga.

Menurut wawancara peneliti dengan Kepala Sekolah SD Bina Putra, jumlah siswa yang mendaftar di SD Bina Putra menurun sejak pendiriannya di tahun 1966. Jumlah siswa terbanyak terdapat pada tahun 1980an, mencapai angka lebih dari dua ratus (200) siswa. Hal ini dikarenakan banyaknya sekolahsekolah lain yang semakin bermunculan di sekitar wilayah Ngagel, khususnya sekolah negeri yang beberapa waktu lalu tidak ada. Siswa di SD Bina Putra saat ini kebanyakan berasal dari warga sekitar Ngagel Rejo. Sebagian besar adalah anak-anak dari penjaga makan Islam Ngagel Rejo, anak-anak tukang becak, tukang ojek dan warga sekitar (Sunarti, personal communication, April 2014). Kebanyakan di antara siswa siswi SD Bina Putra merupakan anakanak yang tidak mampu. Kebanyakan di antara mereka pun bersekolah tanpa membayar.

Majalah dinding Bina Putra merupakan souvenir yang diberikan oleh Pepsodent pada saat Pepsodent melaksanakan program CSR (Corporate Social Responsibility) di SD Bina Putra. Majalah dinding tersebut terbuat dari papan dengan permukaan dari karet spons berwarna hitam. Dimensi majalah dinding tersebut adalah $200 \mathrm{~cm} \times 200 \mathrm{~cm}$. Hasil observasi peneliti menunjukkan bahwa secara fisik, mading di Bina Putra tidak layak lagi digunakan karena selain sudah usang, mading juga sering terkena air hujan. Hal ini menyebabkan materi yang ditempel di madding seringkali menjadi basah ketika turun hujan dan karya-karya siswa tidak bisa lagi terbaca. Majalah dinding tersebut diberi nama "Bersama Berbagi Ilmu".

Pada bulan April 2014, majalah dinding ini diperbaharui sebagai bagian dari sebuah program Pengabdian Masyarakat yang dilakukan oleh pengajar Universitas Kristen Petra, Surabaya. Program ini juga dibarengi dengan penelitian yang mendalami tingkat pengetahuan siswa terhadap majalah dinding di SD Bina Putra.

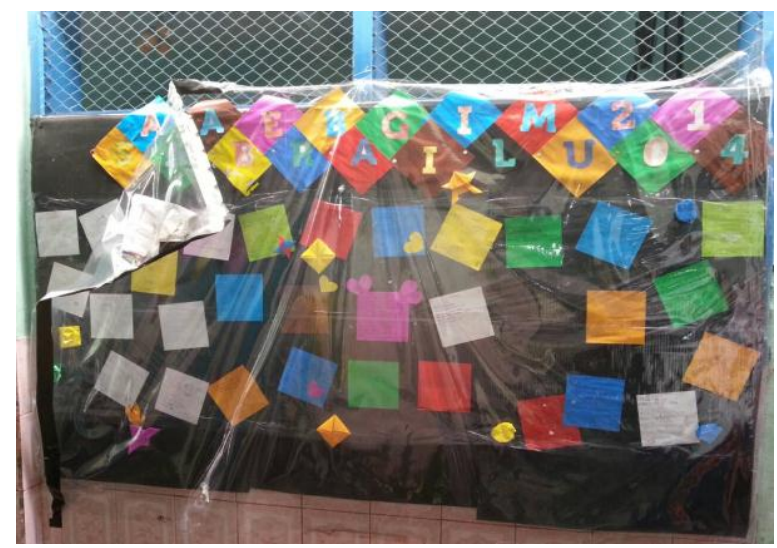

Gambar 1. Majalah Dinding SD Bina Putra sebelum diperbaharui

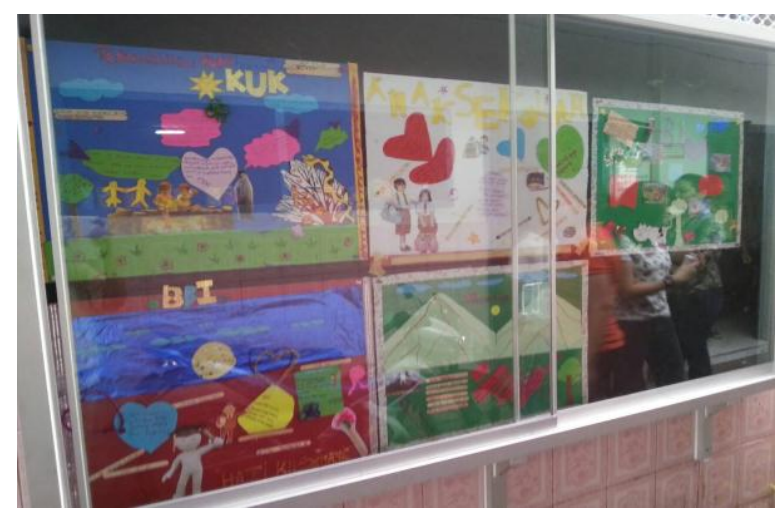

Gambar 2. Majalah Dinding SD Bina Putra setelah diperbaharui

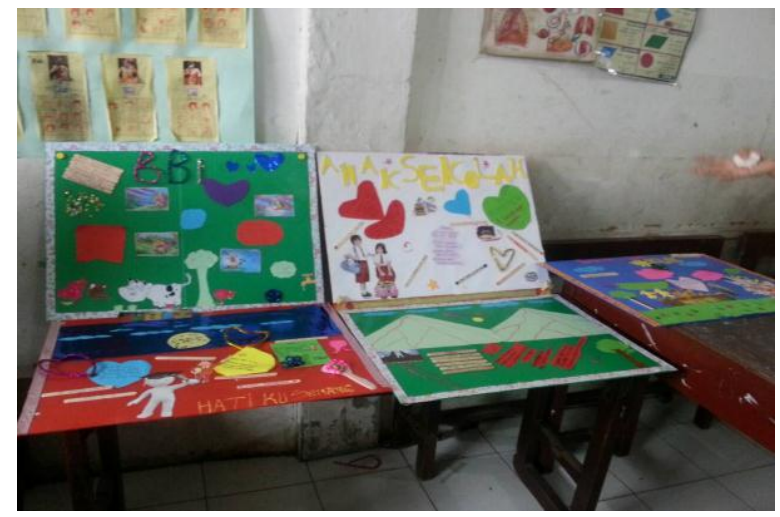

Gambar 3. Karya Siswa-siswi SD Bina Putra 
Adanya kesenjangan antara apa yang sesungguhnya dapat menjadi konten majalah dinding sebagai sebuah persilangan antara media organisasi dan media massa dengan apa yang sebenarnya ada di majalah dinding sekolah ini membuat peneliti tertarik untuk mendalami bagaimana sebenarnya pengetahuan siswa tentang informasi yang terkandung dalam majalah dinding. Ditambah lagi dengan pentingnya mading di tengah terbatasnya media komunikasi yang dapat diakses oleh siswa di sekolah ini, penelitian ini akan mengungkapkan bagaimana kognisi siswa yang terlibat dalam penyusunan majalah dinding tentang mading itu sendiri.

\subsection{Rumusan Masalah dan Tujuan Penelitian}

Berdasarkan paparan latar belakang tersebut di atas maka rumusan masalah dalam penelitian ini ialah: Bagaimanakah tingkat pengetahuan siswa-siswi SD Bina Putra tentang mading sekolah ? Tujuan penelitian adalah untuk menganalisis tingkat pengetahuan pelajar SD Bina Putra tentang informasi yang tersedia di mading sekolah.

\subsection{Manfaat Penelitian}

Literatur maupun penelitian mengenai media organisasi lebih banyak dilakukan pada organisasi yang berorientasi profit, sebaliknya peneliti menemukan minimnya penelitian serupa pada lembaga pendidikan. Penelitian yang komprehensif pada media organisasi dari pelbagai jenis lembaga akan memberikan gambaran besar yang berkontribusi pada perencanaan komunikasi antara organisasi dengan publiknya melalui media organisasi.

\subsection{Batasan Penelitian}

Subyek penelitian ini ialah SD Bina Putra yang terletak di jalan Ngangel Rejo, Surabaya. Responden dalam penelitian ini adalah siswa-siswi kelas 4-6, mengingat rentang kelas 4-6 sudah bisa membaca dan menulis dengan baik sekaligus berpartisipasi dalam pengelolaan mading. Objek penelitian ini adalah tingkat pengetahuan terhadap majalah dinding sekolah yang dibagi berdasarkan tiga kategori yaitu pengetahuan terhadap fungsi, sifat dan format majalah dinding.

\section{TINJAUAN PUSTAKA}

\subsection{Komunikasi Dalam Perspektif Psikologis}

Proses komunikasi dalam perspektif ini menjelaskan bahwa proses komunikasi bergantung pada rangkaian proses psikologis yang terjadi dalam pikiran manusia. Perspektif psikologis lebih berfokus pada individu manusia dan mekanisme internal penerimaa dan pengolahan informasi atau pesan. Perspektif psikologis menekankan pada (1) penerimaan stimuli oleh indera, (2) mediasi internal stimuli, (3) prediksi respon, dan (4) peneguhan (reinforcement) respon. Trenholm (2005) memaparkan : perspektif psikologis meyakini bahwa komunikasi berasal dari dan diterima oleh pikiran manusia. Dengan demikian makna dipertukarkan melalui transmisi stimuli dan penerimaan stimuli.

\subsection{Teori Stimulus-Organisme-Respon (S-O-R)}

Hovland, Janis dan Kelly (1953, dalam Rahmat, 2004) memandang komunikasi sebagai sebuah proses di mana seorang individu komunikator menyampaikan stimuli untuk mengubah perilaku komunikan. Setelah menerima stimuli, indera manusia akan mengolah dalam pikiran dan menghasilkan perilaku tertentu. Pada tahap ini, teori S-R (Stimulus Respon) menjelaskan bahwa stimulus adalah sebuah input, sementara respon adalah sebuah output yang dihasilkan melalui stimulus tersebut.

\subsection{Tingkat Pengetahuan}

Menurut Jalaludin Rahmat (2001, p. 219), "efek kognitif terjadi bila ada perubahan pada apa yang diketahui, dipahami atau dipersepsikan khalayak. Dan efek ini berkaitan dengan transmisi pengetahuan, keterampilan, kepercayaan atau informasi”. Dari definisi di atas dapat disimpulkan bahwa efek kognitif merupakan efek komunikasi di tingkat yang paling mendasar dan terjadi pada tingkat pengetahuan.

Engel, Blackwell dan Miniard mendefiniskan pengetahuan sebagai informasi yang disimpan di dalam ingatan (Engel, Blackwell, \& Miniard, 1994, p. 316). Sedangkan tingkat pengetahuan adalah seberapa banyak informasi yang tersimpan dalam ingatan ketika seseorang menerima sebuah informasi, apakah tinggi, sedang, atau rendah (Engel, Blackwell, \& Miniard, 1994, p. 337).

\subsection{Media Internal}

Dalam upaya menjangkau khalayak tertentu diperlukan media internal. Media internal merupakan salah satu bentuk kegiatan komunikasi Antara dua pihak yang berhubungan, yaitu antara korporasi (organisasi) dan pembaca. Sebagai suatu kegiatan komunikasi, penerbitan media korporasi atau organisasi dimak- 
sudkan untuk memenuhi kedua pihak. Salah satu bentuk media organisasi yakni majalah dinding.

\subsection{Majalah Dinding}

Surat Kabar The New York Times mencatat bahwa sejarah penyebaran berita tertulis dimulai di Roma dengan dua jenis media yaitu "acta senatus" yang berisi catatan kegiatan-kegiatan di Senat dan "acta diurna" berisi rangkuman peristiwa-peristiwa terkini, meliputi laporan-laporan tentang hukum dan ceritacerita human interest. Bentuk acta tersebut berupa lembaran-lembaran yang ditulis tangan dan dipublikasikan dalam frekuensi harian dengan cara ditempelkan di tempat-tempat publik. Majalah dinding atau yang biasa diakronimkan menjadi mading merupakan satu jenis media komunikasi internal tulis yang paling sederhana. Disebut majalah dinding karena prinsip majalah terasa dominan didalamnya, sementara itu penyajian biasanya dipampang pada dinding atau sejenisnya (Nursisto, 1999, p. 1).

Menurut Nursisto (1999, pp. 2-8), majalah dinding, khususnya ada di sekolah dapat memberikan beberapa manfaat, antara lain sebagai (1) media komunikasi, (2) media kreativitas, (3) media untuk meningkatkan keterampilan menulis, (4) media untuk membangun kebiasaan membaca, (5) pengisi waktu, (6) media untuk melatih kecerdasan berpikir, (7) media untuk melatih berorganisasi.

\subsection{Kategori Informasi Dalam Media Komunikasi Internal}

Menurut Siregar dan Pasaribu (2000, pp. 63-70) isi informasi dalam media komunikasi internal harus sesuai dengan tujuan penerbitan. Dalam media komunikasi internal ini, jika diimplementasikan pada majalah dinding dikategorikan menjadi fungsi, sifat dan format majalah dinding, yang dapat dipaparkan sebagai berikut:

Kategori informasi berdasarkan fungsi, yang dibedakan menjadi tiga bagian yakni:

- Fungsi informative, apabila informasi yang disampaikan menambah pengetahuan baru bagi pembaca.

- Fungsi edukatif, apabila informasi itu memperkenalkan cara kepada pembaca tentang cara baru untuk melakukan suatu kegiatan atau untuk mengatasi suatu masalah.

- Fungsi menghibur, apabila menyajikan informasi yang sifatnya menghibur sekaligus menawarkan variasi.
Ketegori informasi berdasarkan sifat dibagi menjadi 3 yaitu:

- Informasi faktual, diperoleh berdasarkan fakta dari peristiwa nyata yang terjadi.

- Informasi faksional, berdasarkan pendapat seseorang mengenai fakta yang terjadi.

- Informasi fiksional adalah hasil rekaan pikiran seseorang yang disusun bukan berdasarkan fakta yang terjadi.

Kategori informasi berdasarkan format, dibedakan menjadi:

- Berita adalah laporan tertulis mengenai suatu peristiwa, kegiatan dan sejenisnya yang terjadi di dalam atau diluar organisasi (yang ada hubungannya dengan organisasi).

- Artikel berupa ulasan yang memperlihatkan sisi baik atau buruk maupun untung atau rugi yang mungkin ditemukan dalam suatu masalah.

- Fiksi adalah tulisan yang disusun berdasarkan rekaan penulis.

- Foto atau bagan merupakan informasi yang disajikan sebagai satu kesatuan atau juga sebagai pelengkap bagi suatu tulisan.

\section{METODE PENELITIAN}

Dalam penelitian ini, peneliti menggunakan pendekatan kuantitatif. Jenis penelitian yang digunakan peneliti adalah penelitian deskriptif. Metode penelitian yang akan digunakan adalah metode survey dengan menggunakan kuisioner sebagai instrument pengumpulan datanya.

Subjek dari penelitian ini adalah Siswa-siswi SD Bina Putra. Populasi dalam penelitian ini adalah seluruh siswa-siswi SD Bina Putra kelas 4, 5 dan 6 yang berjumlah 28 siswa (tercatat 34 siswa, tidak hadir 6 siswa pada hari pengumpulan data). Sedangkan teknik sampling yang digunakan peneliti adalah total sampling.

\section{HASIL DAN PEMBAHASAN}

\subsection{Deskripsi Responden}

Siswa Sekolah Dasar (SD) Bina Putra yang disurvey terdiri dari 28 orang. Diketahui bahwa dari 28 responden yang diteliti, prosentase terbesar adalah siswa/i yang berusia 11 tahun dengan prosentase $35,7 \%$, usia 12 tahun dengan prosentase $32,1 \%$, usia lebih dari 12 sebanyak 7 responden (25\%), sedangkan siswa/i yang berusia 10 tahun sebanyak 2 responden dengan prosentase $7,1 \%$. Dari hasil rata-rata terbesar 
dalam penelitian ini, terlhat bahwa usia 11 tahun merupakan usia reponden terbanyak. Selanjutnya, mengenai jenis kelamin, menunjukkan bahwa frekuensi terbesar responden didominasi oleh jenis kelamin laki-laki sebanyak 16 responden siswa/i dengan prosentase $57,1 \%$ sedangkan perempuan sebanyak 12 responden dengan prosentase $42,9 \%$. Hal ini menunjukkan rata-rata responden memiliki jenis kelamin laki-laki.

Mengenai kelas responden, hasil penelitian menunjukkan bahwa responden terbanyak di kelas 6 dengan frekuensi sebanyak 11 responden, prosentase $39.3 \%$, dan kelas lima sekolah dasar jumlah frekuensi sebanyak 10 dengan prosentase $35.7 \%$, sedangkan untuk kelas 4 sekolah dasar berjumlah 7 responden dengan prosentase $25 \%$. Hal ini menunjukkan ratarata terbesar responden berada di kelas 6 dan 5 Sekolah Dasar. Responden terbanyak yang mengetahui mading SD Bina Putra dengan jumlah frekuensi responden sebanyak 23 responden dengan prosentase $82,1 \%$. Sedangkan 5 responden atau prosentase $17,9 \%$ menjawab tidak tahu mengenai mading SD Bina Putra.

Jadi dapat disimpulkan pada data responden siswa terbanyak pada majalah dinding (Mading) SD Bina Putra menunjukkan bahwa responden adalah para siswa/i SD Bina Putra yang saat ini berusia 11 tahun, dengan jenis kelamin laki-laki dan duduk di bangku sekolah dasar kelas 5 dan 6 dan umumnya mereka mengetahui mading di Sekolah Dasar Bina Putra.

Menurut Piaget, usia 7-11 tahun termasuk dalam tahap operasional konkret (concrete operational stage) yaitu tahap di mana seorang anak dapat mendemonstrasikan pemikiran yang logis dan terintegrasi. Pada tahap ini, perkembangan anak terbatas pada kemampuan mengaplikasikan pengetahuan mereka pada stimuli dan objek yang konkret (p. 4). Pembatasan ini sesuai dengan tujuan penelitian ini yaitu untuk mengetahui bagaimana respons kognitif siswa terhadap stimulus berupa pesan dalam majalah dinding. Selanjutnya, usia 12 tahun, dianggap oleh Piaget sudah masuk dalam tahap operasional formal di mana anak sudah dapat memikirkan konsepkonsep abstrak. Namun, beberapa penelitian (Eylon \& Linn, 1988; Renner et. al., 1976) menemukan bahwa usia secara fisik-dalam hal ini usia 12 tahun - belum tentu menentukan bahwa seorang anak sudah dapat masuk ke dalam tahap operasional formal.

Bahkan menurut Eylon \& Linn, tahap operasional formal belum tentu tercapai hingga seorang individu lulus dari sekolah menengah tingkat atas (high school) yaitu pada usia 17-18. Karena itulah, penelitian ini mengambil responden sampai dengan usia sekolah dasar tertinggi yaitu 12 tahun, dengan dilatarbelakangi oleh gagasan bahwa pada range usia inilah siswa memiliki kemampuan untuk merespon pada stimuli dan objek yang konkret.

Dalam hal jenis kelamin responden, temuan data ini cukup menarik bagi peneliti. Data yang dipublikasikan oleh UNICEF menunjukkan bahwa pada pendidikan tingkat dasar, mulai tahun 2002 tidak terdapat kesenjangan yang signifikan antara jumlah laki-laki dan perempuan yang bersekolah (http:// www.unicef.org/indonesia/girls_education_fact_sheet _final_ENG_1_.pdf). Namun menilik dari latar belakang sekolah Bina Putra sebagai sekolah untuk anak-anak yang kurang mampu, ada kemungkinan bahwa hasil ini merefleksikan kesenjangan gender pada pendidikan yang terjadi pada kelompok underpriviledged children.

\subsection{Tingkat Pengetahuan Siswa Tentang Mading}

Rekapitulasi mean jawaban responden memberikan gambaran tentang tinggi rendahnya tingkat pengetahuan siswa mengenai fungsi majalah dinding, sifat informasi mading serta format informasi yang terdapat pada mading, seperti yang tertera dalam Tabel 1.

Peneliti membagi mean tingkat pengetahuan siswa ke dalam tiga kelas, yaitu, tinggi, rendah dan sedang, dengan penghitungan:

$$
\text { Interval }=\frac{5-1}{5}=0.80
$$

Dari penghitungan tersebut didapatkan interval sebesar 0,80, sehingga skor untuk kategori tingkat pengetahuan sangat tinggi, tinggi, sedang, rendah dan sangat rendah adalah seperti tertera pada Tabel 2 .

Berdasar interval yang telah ditetapkan pada Tabel 2, maka rata-rata tingkat pengetahuan siswa tentang majalah dinding termasuk dalam kategori tinggi (seperti tertera pada Tabel 3). Bila dicermati per indikator, maka temuan tingkat pengetahuan siswa SD Bina Putra tentang mading sekolah termasuk dalam kategori sangat tinggi pada indikator pengetahuan tentang fungsi mading (mean skor = 4,243), dan kategori tinggi pada indikator tingkat pengetahuan tentang sifat mading (mean skor = 3,750 ) dan format mading (mean skor 4,007). Adapun perbandingan tinggi tingkat pengetahuan siswa, peneliti ilustrasikan seperti tergambar pada grafik (Gambar 4 dan 5). 
Tabel 1. Mean Skor Tingkat Pengetahuan

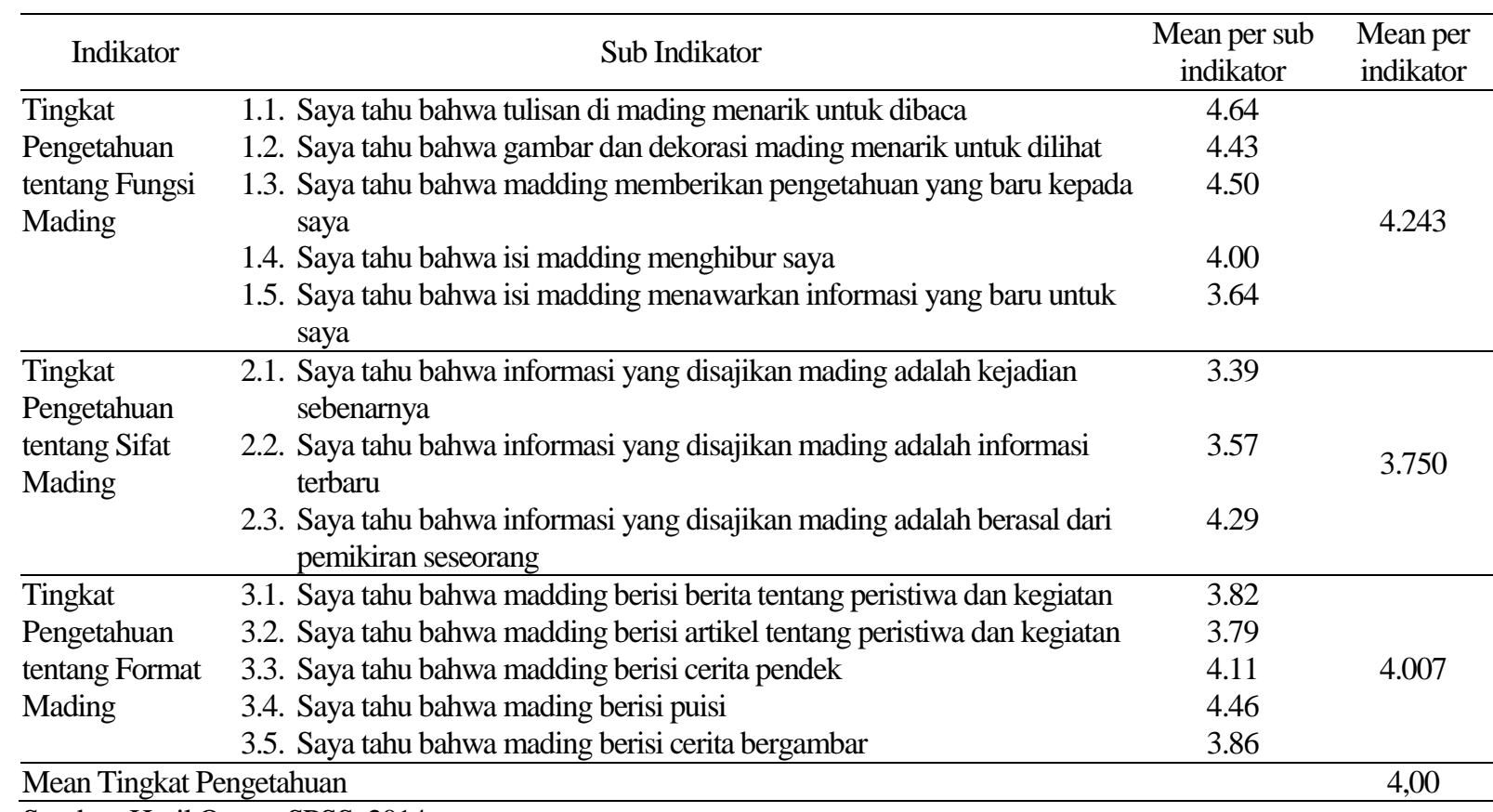

Sumber: Hasil Output SPSS, 2014

Tabel 2. Kategori Skor berdasar Interval

\begin{tabular}{clc}
\hline No. & \multicolumn{1}{c}{ Kategori } & Skor \\
\hline 1. & Sangat rendah & $1-1,8$ \\
2. & Rendah & $1,81-2,61$ \\
3. & Sedang & $2,62-3,42$ \\
4. & Tinggi & $3,43-4,23$ \\
5. & Sangat Tinggi & $4,24-5,00$ \\
\hline
\end{tabular}

Tabel 3. Kategori Tingkat Pengetahuan berdasar Interval

\begin{tabular}{cccc}
\hline No. & Variabel & Mean & Kategori \\
\hline 1. & Tingkat pengetahuan & 4,00 & Tinggi \\
\hline
\end{tabular}

Rata-rata Tingkat Pengetahuan

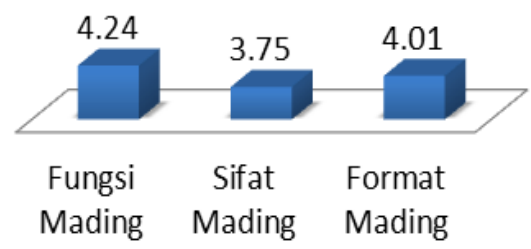

Gambar 4. Grafik Batang Rata-Rata Tingkat Pengetahuan Siswa tentang Majalah Dinding SD Bina Putra

\subsection{Pembahasan}

Menurut Hovland, Janis dan Kelly (1953), stimulus (rangsang) yang diberikan pada organisme dapat diterima atau ditolak. Manakala stimulus tidak diterima berarti stimulus itu tidak mempengaruhi perhatian individu dan berhenti disini. Tetapi bila stimulus diterima oleh organisme berarti ada perhati- an dari individu dan ia mengerti stimulus ini. Hasil penelitian ini menunjukkan bahwa siswa SD Bina Putra telah menerima stimulus berupa informasi yang disajikan pada majalah dinding dan telah mengerti stimulus ini. Hal ini terbukti dari tingginya respon kognitif mereka terhadap fungsi, sifat maupun format majalah dinding sebagai media organisasi di sekolah mereka. Dengan menggunakan pendekatan teori S-O$\mathrm{R}$, penelitian ini membuktikan bahwa stimulus berupa informasi pada majalah dinding dapat diterima dengan baik oleh siswa dan mereka mampu merespon secara kognitif.

Rata-raata Tingkat Pengetahuan per Sub Indikator

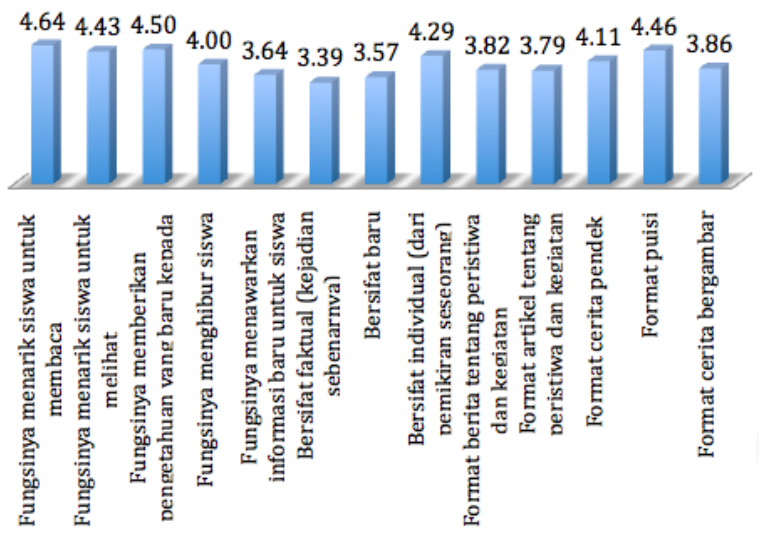

Gambar 5. Grafik Batang Rata-Rata Tingkat Pengetahuan Siswa tentang Majalah Dinding SD Bina Putra(Per sub indikator) 
Dengan tingginya tingkat pengetahuan mereka, hasil penelitian ini juga membuktikan bahwa ada kesadaran (awareness) yang tinggi pada siswa terkait dengan informasi pada majalah dinding. Namun, bila dicermati lebih jauh, ada beberapa variasi pada data yang menunjukkan bahwa sebagai sebuah media komunikasi, majalah dinding tersebut dapat ditingkatkan lagi.

Bila dikaitkan dengan teori tentang manfaat majalah dinding sekolah (Nursisto, 1999), beberapa manfaat majalah dinding telah didapatkan oleh responden penelitian ini. Pertama, mading ini telah bermanfaat sebagai media komunikasi warga sekolah, khususnya siswa kelas 4, 5 dan 6. Siswa mengetahui bahwa majalah dinding menarik mereka untuk melihat, membaca dan memberi pengetahuan . Hal ini senada dengan pendapat Nursito bahwa lewat mading, "bermacam informasi dapat disebarkan secara mudah.. dan banyak hal yang semula tidak diketahui akhirnya menjadi perbendaharaan pengetahuan".

Selanjutnya, penelitian ini juga menunjukkan bahwa siswa mengetahui bahwa mading adalah sebagai media untuk menyalurkan kreativitas. Hal ini ditunjukkan melalui tingginya tingkat pengetahuan tentang format konten mading berupa puisi, cerita pendek dan cerita bergambar. Nursisto (1999) juga menjelaskan bahwa mading sekolah merupakan tempat menampung kreativitas siswa. Ia juga memaparkan bahwa "dari sisi penulis, majalah dinding merupakan tempat untuk mencurahkan berbagai macam ide, beragam gagasan, pikiran, daya cipta bahkan fantasi yang mengiringi perkembangan jiwa siswa" (dalam Santoso, p. 7). Tingginya tingkat pengetahuan siswa tentang mading sebagai sarana kreativitas dapat disebabkan karena responden penelitian ini merupakan siswa yang tidak hanya menjadi audiens tetapi juga menjadi penulis dan pembuat karya yang ditampilkan di mading.

Tingkat pengetahuan yang tinggi pada sub indikator format berita, artikel, cerita pendek dan cerita bergambar juga menunjukkan bahwa mading SD Bina Putra dimanfaatkan untuk melatih kemampuan menulis siswa.

Temuan penelitian ini mengindikasikan bahwa ada satu aspek dalam mading yang perlu ditingkatkan yaitu mengenai isi mading yang bersiftat jurnalistik. Dari hasil tingkat pengetahuan sedang yang terdapat sub indikator sifat mading yang faktual mengindikasikan bahwa siswa SD Bina Putra masih belum sepenuhnya menyadari aspek jurnalistik dari majalah dinding sebagai media yang dapat memberitakan kejadian-kejadian faktual di seputar organisasinya. Penting bagi mading untuk dapat memuat nilai-nilai, harapan maupun aktivitas-aktivitas yang dilaksanakan di organisasi sehingga publik internal sekolah dapat berpartisipasi dalam merealisasikan tujuan organisasi.

Bila dikaitkan dengan tujuan komunikasi (Suprapto, p. 13), majalah dinding sebagai media komunikasi siswa telah mencapai tujuan menghibur dan mendidik, tetapi belum memaksimalkan aspek memberikan informasi. Hal ini dapat dicapai dengan cara menambahkan konten-konten faktual. Aspek lain yang dapat ditingkatkan lagi adalah pada sifat kebaruan majalah dinding.

\section{KESIMPULAN}

Hasil penelitian ini menunjukkan bahwa respon kognitif siswa SD Bina Putra terhadap fungsi, sifat maupun format majalah dinding sebagai media organisasi di sekolah mereka adalah tinggi. Dengan menggunakan pendekatan teori S-O-R, penelitian ini membuktikan bahwa stimulus berupa informasi pada majalah dinding dapat direspon secara kognitif dengan baik oleh siswa usia 10-12 tahun. Pengetahuan siswa terhadap fungsi majalah dinding ada dalam kategori sangat tinggi, sementara tingkat pengetahuan terhadap sifat dan format majalah dinding ada dalam kategori tinggi. Secara lebih rinci, tingkat pengetahuan siswa dalam kategori tinggi ada pada sub indikator fungsi mading sebagai media hiburan, sebagai pemberi informasi baru, sifat kebaruan mading, serta format mading berupa berita, artikel, cerita pendek, dan cerita bergambar. Tingkat pengetahuan yang sedang ada pada satu sub indikator yaitu sifat mading yang faktual atau dengan kata lain mengenai konten mading yang berisi kejadian-kejadian sebenarnya.

Temuan ini mengindikasikan bahwa siswa memiliki kesadaran(awareness) yang tinggi pada majalah dinding sekolahnya. Artinya, mading tersebut dapat menjalankan fungsinya sebagai media komunikasi bagi siswa-siswa di sekolah. Namun, beberapa aspek yang dapat ditingkatkan lagi adalah pada sifat kebaruan konten mading, sifat faktual (isi tentang kejadian-kejadian sebenarnya) serta berita dan artikel tentang peristiwa dan kejadian di sekitar sekolah. Hal ini menunjukkan perlunya peningkatan aspek jurnalistik mading sebagai media komunikasi di SD Bina Putra.

\subsection{Saran Akademis dan Praktis}

Penelitian serupa dapat dilakukan terhadap majalah dinding sekolah dapat dilakukan terhadap sekolah lain 
di jenjang yang berbeda, misalnya SMP dan SMA serta sekolah dengan karakteristik siswa yang berbeda, pada khususnya yang memiliki lebih banyak akses terhadap media komunikasi. Menarik pula untuk diteliti apakah terdapat perbedaan yang signifikan antara pengetahuan siswa tentang informasi pada mading di sekolah yang memiliki pelajaran intrakurikuler dan/atau ekstrakurikuler jurnalistik dengan yang tidak mengajarkan konten jurnalistik pada siswanya. Penelitian yang bersifat kualitatif, misalnya yang mendalami penerimaan siswa terhadap konten mading juga menarik untuk dilakukan mengingat majalah dinding sebagai media yang jamak didapati di sekolah-sekolah kini harus "bersaing" dengan media-media dan gadget elektronik yang menawarkan tampilan visual yang lebih dinamis.

Saran lain adalah pembuatan rubrikasi pada majalah dinding. Sekolah dapat membentuk sebuah tim khusus yang terdiri atas siswa-siswi sebagai redaksi majalah dinding. Siswa dapat ditugaskan pada rubrikrubrik yang berbeda agar konten yang dipublikasikan lebih seimbang antara yang bersifat kreatif dengan yanginformatif. Karena karakteristik sekolah dan keterbatasan sumber daya yang ada, rekomendasi peneliti adalah perlu adanya kemitraan dengasn institusi-institusi eksternal yang berkompeten untuk melakukan pendampingan dan pembimbingan secara berkesinambungan bagi siswa dan guru untuk dapat memfungsikan mading sebagai media komunikasi bagi sivitas akademika sekaligus melatih keterampilan dan kreativitas siswa.

\section{DAFTAR REFERENSI}

Care.org, (2006). Facts about Children and Poverty. Diunduhtanggal 20 Juli 2014 dari http://www. care.org/work/poverty/child-poverty/facts.

Engel, J. F., R. D, Blackwell, P. W., \& Miniard. (1994). Perilaku Konsumen. Jakarta: Binarupa Aksara.

Eylon, B. \& Linn, M. (1988). Learning and instructtion: An examination of four research perspectives in science education. Review of Educational Research, 58(3), 251-301.

Jefkins, F. (1994). Public Relations Untuk Bisnis. Jakarta: PT Pustaka Binaman Pressindo.

Hovland, C. I., Janis, I. L. and Kelley, H. H. (1953) Communications and persuasion: Psychological studies in opinion change, New Haven, CT: Yale University.

Lutz, S. \& Huitt, W. (2004). Connecting cognitive development and constructivism: Implications from theory for instruction and assessment. Constructivism in the Human Sciences, 9(1), 6790.
McQuail, D. (2005). Mass Communication Theory. London: Sage.

Mulyana, D. (2004). Pengantar Ilmu Komunikasi. Jakarta: PT GramediaWidiasarana Indonesia.

Moore, H. F. (2004). Humas: Membangun Citra dengan Komunikasi. Bandung: Remaja Rosdakarya.

Nursisto. (1999). Membina Majalah Dinding. Yogyakarta: Adicita Karya Nusa.

OECD (Organisation for Economic Co-operation and Development) (25-26 Mei 2011). Meeting of the OECD Council at the Ministerial Level. Diunduhtanggal 20 Juli 2014 dari http://www. oecd.org/education/48111145.pdf

Ojose, B. (2008). Applying Piaget's Theory of Cognitive Development to Mathematics Instruction. Dalam The Mathematics Educator, 18(1), 2630.

Rakhmat, J. (2001). Metode Penelitian Komunikasi. Bandung: PT. Remaja Rosdakarya.

Rakhmat, J. (2004). Psikologi Komunikasi. Bandung: PT. Remaja Rosdakarya.

Renner et. al. (1976). Research, teaching, and learning with the Piaget model. Norman, OK: University of Oklahoma Press.

Rifai, M. (1992). Teknik Membuat dan Menerbitkan Majalah Dinding. Makalah disampaikan dalam Kegiatan PKMTD HMP IKIP Malang, Himpunan Mahasiswa Penulis, 17, 18-25, 25 Oktober 1992.

Santoso, H. (2007). Majalah Dinding sebagai Media untuk Meningkatkan Kemampuan Menulisdan Budaya Baca Siswa. Malang: UPT Perpustakaan Universitas Negeri Malang.

Santoso, S. (2003). Statistik Deskriptif Konsepdan Aplikasi dengan Microsoft Excel dan SPSS. Yogyakarta: Andi.

Siregar, A. \& Pasaribu, R. 2000. Bagaimana Mengelola Media Korporasi Organiasai. Yogyakarta: Lembaga Penelitian, Pendidikan dan Penerbitan Yogya (LP3Y)

UNICEF, (n.d.) Facts : Girls Education in Indonesia. Diunduh tanggal 18 September 2014 dari http://www.unicef.org/indonesia/girls_education _fact_sheet_final_ENG_1_.pdf

Widayati, R. 1996. Pengaruh Kualitas Majalah Dinding terhadap Kemampuan Menulis Siswa Kelas I SMUN Kepanjen Tahun Pelajaran 1995/1996. Malang: JPBSI FPBS IKIP Malang.

Williams (11 Maret 2013), Why girls in India are still missing out on the education they need. Diunduh tanggal 1 Oktober 2014 dari http://www.the guardian.com/education/2013/mar/11/indianchildren-education-opportunities. 